\title{
CORRUPTION PREVENTION SYSTEM IN THE BORDER GUARD AGENCIES (STATE BORDER GUARD SERVICE OF UKRAINE AS AN EXAMPLE)
}

\author{
Natalya Orlovska \\ Doctor in Law, Professor, Odessa National Maritime University, Ukraine \\ e-mail: natalyaorlovska@ukr.net, orcid.org/0000-0002-4400-560X
}

\section{Yuliia Stepanova}

Ph.D. (Law), Deputy Chief of Science Research Department, National Academy of the State Border Guard of Ukraine named after Bogdan Khmelnitsky, Ukraine e-mail: yulia.sp81@ukr.net,orcid.org/0000-0001-7698-3486

\section{Summary}

The article is devoted to the model of anti-corruption system building study using State Border Guard Service of Ukraine as an example. The content of this system certain elements depending on corruption risks and the factors that affect them is analyzed. This takes into account the corruption level and its prevention experience in the border guard agencies of some foreign countries. It is noted that the state border protection and defense effectiveness directly depends on the degree of anti-corruption system efficiency rate.

A number of theoretical and applied nature conclusions are formulated. Among them are the following ones:

State Border Guard Service of Ukraine anti-corruption system is characterized by international, domestic and departmental institutions and instruments interaction. It is a part of domestic anti-corruption system and includes such elements: object, goals, principles, legal framework, participators and prevention measures;

range of participators involved in State Border Guard Service of Ukraine corruption prevention extends beyond the borderguard agency. It is proposed to consideranti-corruption participators powers based on such classification: 1) international actors; 2) domestic actors: governmental institutions (special anti-corruption authorized agencies and state bodies involved in the corruption prevention); departmental bodies for corruption prevention; non-government organizations, individuals and legal entities;

corruption prevention in State Border Guard Service of Ukraine should be based on selfservice activities for integrity and staff corruption resistance level increasing. Combating illegal activities at the state border is also actual for anti-corruption objectives achieving.

Keywords: border guard agency; corruption delicts; corruption prevention participators; general social and special criminological anti-corruption measures; anti-corruption resilience.

DOI: https://doi.org/10.23856/4815

\section{Introduction}

Within the corruption prevention framework there are three interrelated areas: 1) anticorruption legislation formation that would meet international standards; 2) specialized anticorruption institutions system creation; 3) public authorities (including military formations) system reforming based on integrity and transparency. 
When considering the borders guard agencies researchers emphasize such corruption risks of border protection activities: 1) insufficient external control; 2) a high level of autonomy and discretionary powers of these bodies; 3 ) economic factors motivating traders to corruption schemes; 4) organized crime pressure; 5) inadequate wages and working conditions of border guards; 6) specific organizational features of state border guard agencies' structure units. Consequently,border corruption has a detrimental impact on shipping costs, trade, revenue collection, illegal migration as well as organized crime and security (Chene, 2018: 1).

In view of this, it is important to form a border guard agency that is resistant to illegal influences. Such development vector was chosen by State Border Guard Service of Ukraine (hereinafter - SBGSU). In accordance with the existing threats, a system of "internal security" was formed. It includes preventing corruption system in SBGSU.

This article purpose is to study the characteristics of the corruption prevention system in SBGSU, including problems of its effectiveness.

To achieve this goal, there were used such research methods:

systemic and structural-functional methods usinghas ensured the consideration of elements of the corruption prevention system in SBGSU;

methods of analysis and synthesis application has helped to analyze the scientific literature about corruption prevention in border agencies, to identify the relationship between cross-border crime and corruption prevention system elements, to investigate this system elements structure and content;

comparative method was used in order to study of corruption risks and their impact in different countries border agencies corruption.

\section{Review of scientific research to prevent corruption in the border agencies activity}

Theoretical and practical problems of preventing corruption in the border agencies of the EU and the US paid attention by Chene M. (2018), Sharon I. Kwok (2020), Hennop E., Jefferson C., Mclean A. (2001), Martin Hrabalek (2010), Mungiu-Pippidi A. (2015), Morarou V. (2013), Komlavi Hahonou E. (2016),etc.

Many experts` researches deal with corruption in border and customs agencies due to their activities common features.In addition, structurally these agencies in many countries are part of the police (Austria, Belgium, Hungary, Germany, Greece, Denmark, Iceland, Spain, Italy, Cyprus, Norway, Portugal, Slovenia, France, Croatia, Sweden, Estonia) or the armed forces (Malta, the Netherlands).

In the United States there is a joint border agency that performs border and customs functions (US Customs and Border Protection, which is part of the Department of Homeland Security). Therefore, border guards and customs officers ' delicts are also analyzed together.

For example, the San Diego State University researchers examined 156 cases taken from October 2004 to October 2015 - with the majority occurring in Texas, California and Arizona. According to the data, about two-thirds of the cases involved customs officers with the remaining third involving border patrol agents.Customs officers were typically paid for their help in getting drugs across the border while border patrol agents were bribed for their knowledge of smuggling routes and how border crossing security system works. The personal approach fruitfulness is also emphasized. So, David Janscics has come to the conclusion that the experience level of an official correlating to the type of corruption they would be involved in: younger agents (less than five years of experience) were more likely to be charged with drug or weapons trafficking offences, while more senior agents were more likely to be involved in human smuggling (Wells, 2019). 
Interesting are the Dutch researcher M. Chene results. She studied corruption at the borders within the research of the anti-corruption association U4, created under Chr. Michelsen Institute (CMI) in Norway. Her work considersparallel formscustoms and border guard agencies corruption, highlighting their common features. The author identifies increasing corruption risks factors and neutralizing these factors anti-corruption measures.

The scientist concludes that trafficking of drugs, natural resources, weapons, stolen vehicles or even consumer goods such as oil, alcohol or cigarettes also rely on smuggling and on avoiding investigation, which is facilitated by corruption, including border corruption. Corruption also plays a large role in facilitating cross-border the smuggling of weapons and insurgents, which are the used to undermine state stability and the functioning of state institutions (Chene, 2018: 16, 18).

Important conclusions about border agency formation on the professionalism and integrity basis on the example of the European Border and Coast Guard Agency (FRONTEX) makes Czech scientist Martin Hrabalek in his dissertation study "EU border protection and the role of FRONTEX in it"(Hrabalek, 2010).

However, since this study FRONTEX anti-corruption measures have been improved by defining provisions in the Regulation (art. 117, 118) concerning conflicts of interest prevention, the transparency register introduction and the principles of cooperation with the European AntiFraud Office (OLAF) in internal investigations (Regulation (EU) 2019/1896).

The Ukrainian model of border protection institutional providing envisages a separate agency - the SBGSU as a law enforcement agency of special purpose. It is a part of the security and defense sector of Ukraine. Corruption prevention researches in SBGSU have been carried out for a long time by such specialists as V. Khirny (2013), Y. Kuryliuk (2018, 2020), V. Zolka (2013), S. Khalymon (2017), S. Filippov (2019).

The scientific intelligence generalization permits to note activity approach dominance to corruption in SBGSU analysis. Such offenses are antisocial practice, which reveals corrupt border guard personal characteristics (Filippov, 2019; Kurilyuk, 2019, 2020). At the same time institutional approach seems also fruitful one. Itis manifested in the SBGSU structure and powers bringing to international standards (Filippov, Ziolka, 2013).

Simultaneously scientific research tends to focus on specific issues, although corruption preventing is a part of delinquency avoiding. In addition, there are no analytics reflecting a holistic system for corruption preventing in border agencies, including SBGSU.

\section{Model of corruption prevention system in SBGSU}

Starting this issue analysis, it should be noted that statistics in Ukraine do not confirm the David Janscics' conclusion that border agencies all around the world are generally more corrupt than other public agencies (Wells, 2019). Thus, according to official statistics from 2008, 30-40 border guards are sentenced to criminal liability for committing various criminal offenses each year. Of all border guards convicted in 2014-2019, 25.77\% (92 people) were found guilty of committing corruption offenses.

The corruption delinquency level in SBGSU was 38 criminal offenses during 2020. Most often, border guards accept the offer, promise or receive illegal benefits (over 75\%). At the same time, there are positive trends in border guards' reaction to involving into illegal activities. Thus, during 2020, 583 attempts to provide illegal benefits for SBGSU staff were suppressed (DPSU. Antykoruptsiinyi biuleten, 2020, 2021). 
Thus, in no case can it be said that border guards are extremely corrupt compared to other law enforcement officers.

The corruption prevention system both in Ukraine as a whole and in SBGSU, in particular,is not reflected in a certain legislative act. This is a theoretical model based on a number of regulations and practical measures to prevent corruption.

In our opinion, the corruption prevention system in SBGSU covers the following elements: 1) object; 2) goals; 3) principles; 4) legal framework; 5) participators; 6) prevention measures.

1. The corruption prevention object in SBGSU - corruption-causing factors, corruption risks (Golovkin, 2018: 254-260) in the SBGSU activities, its staff illegal behavior.

Corruption risks considering border guard service as whole depend on authorities' official activity type. Thus, corruption risks in state border protection may be border guards dishonest behavior in relation to:

suppression of offenses at the border leading to illegal movement of goods / objects and illegal migrants;

foreign citizens legalization in Ukraine;

passage through the state border ofUkraine citizens who are prohibited from entering or leaving its territory;

failure to enter information or entering inaccurate information into the departmental database of persons and vehicles crossing the state border;

illegal personnel decisions, etc.

These delicts are associated with unauthorized routes change or deliberate duty stations abandonment; insufficient level of knowledge requirements of anti-corruption legislation by SBGSU staff (Zvit pro vykonannia Antykoruptsiinoi prohramy DPSU na 2020-2022 roky).

Similar corruption risks can be identifiedforother states border agencies activities. Their detection in specific offenses depends on a number of factors. Analyzing border corruption, M. Chene identifies factors that increase corruption risks in border regions (Chene, 2018: 2-6):

a) Geographic dispersion. Border officials often lack resources and adequate supervision as they operate in remote and geographically dispersed areas that make careful supervision almost impossible while enjoying wide discretionary powers that provide them with opportunities to extract bribes. In many countries, this situation is exacerbated by poor infrastructure, lack of human and institutional capacity, low levels of automation and computerization, lack of training and professionalism, low public service salaries, and weak controls and oversight;

b) Size of border configuration. In the EU, for example, larger border crossings along the eastern land borders and major international seaports are typically well staffed, well resourced, with well developed infrastructure including sophisticated anticorruption measures such as video-monitoring. According to researchers at the Center for the Study of Democracy (2012), where corruption occurs at major border crossings, it requires more sophisticated and financially costly schemes that commonly involve cooperation between several border guards, or more complex collaboration between teams of border guards, customs officers and sea-port employees. At smaller border crossings, corruption more often involves doing favours for friends and family. In some cases, it is a family tradition that different generations or spouses work in the same agency, which also contributes to the existence of informal networks for the corruption development. However, in small units, border guards are more cohesive, so it is harder to hide corruption. In such units, border guard forces are either generally corruption-free, due to strong team ethics, or are institutionally corrupt; 
c) Administrative monopoly and discretionary. Border guards enjoy comparatively fewer discretionary powers than customs officials. And they have fewer opportunities to extort bribes from legitimate businesses and individuals. There are three major areas where border guards may become involved in extortion: 1) migration control; 2) schemes where they become complicit with customs officials who extort money from legitimate companies and private persons; 3) administrative corruption regarding public contracts;

d) Wages and working conditions. The combination of low pay, difficult service conditions and low detection control rates encourages corruption;

e) Complex regulatory frameworks. Nontransparent, burdensome rules and procedures constitute vulnerabilities that;

g) Pressure from organized crime. The movement of illegal goods, people and animals is often controlled by organized criminal groups that engage officials in corrupt practices to facilitate illegal operations.

2. Goals of corruption preventing in SBGSU - transparency, integrity, corruption risks reduction mechanisms introduction and public confidence level in border guards' activity increasing; detection, neutralization, blocking, elimination of factors determining corruption, as well as corruption in SBGSU prevention and suppression.

3. The principles of corruption preventing in SBGSU are considered as a set of guiding requirements for activity organization in order to develop and apply a certain prevention strategy. As a basis for defining such principles are international acts` norms and domestic legislation.

For example, On The Twenty Guiding Principles For The Fight Against Corruption (Council of Europe, 1997) and Istanbul Anti-Corruption Action Plan for Armenia, Azerbaijan, Georgia, Kazakhstan, the Kyrgyz Republic, the Russian Federation, Tajikistan and Ukraine $(O E C D, 2003)$. The international principles reflection can be traced in Ukrainian legislation containing general, legal, managerial, economic principles of state and society interaction, and the anti-corruption activity principles (Zapobihannia ta protydiia koruptsii, 2013).

International anti-corruption standards and domestic legislation provisions were taken into account in SBGSU departmental documents development. Thus, the corruption prevention principles in SBGSU, in accordance with the SBGSU Anti-Corruption Program for 2020-2022 requirements, include: rule of law; integrity in the public service; a negative attitude to corruption formation; the punishment for corruption offenses inevitability; efficiency and legality of the budget funds use; transparent and open activities; public involvement in anti-corruption measures; creation of partnership with civil society institutions mechanisms (Antykoruptsiina prohrama DPSU na 2020-2022 roky).

4. The preventing corruption legal framework in SBGSU covers international acts and domestic legislation. The main international acts are the UN Convention against Transnational Organized Crime (2000), the UN Convention against Corruption (2003), Council of Europe Criminal Law Convention on Corruption (1999), and others. In addition, recommendation documents play a significant role, in particular, Council of Europe resolutions on standardization and control of anti-corruption activities, and the provision of technical assistance to countries.

The corruption preventing legislation basis in SBGSU is a system based on the Constitution of Ukraine and includes laws, bylaws (including departmental ones), as well as the Constitutional Court of Ukraine, the Supreme Court and the ECHR practice. This normative set structureis determined bythese acts legal force and their action peculiarities.

This area laws can be classified according to the subject of regulation into laws that determine:

1) anti-corruption policy principles (Grounds of state anti-corruption policy in Ukraine (Anti-corruption strategy) (2014)); 
2) corruption prevention system functioning principles in Ukraine (Law of Ukraine "On Prevention of Corruption" (2014));

3) legal bases of anti-corruption bodies organization and activity (Laws of Ukraine "On the National Anti-Corruption Bureau of Ukraine" (2014), "On the Prosecutor's Office" (2014), "On the Supreme Anti-Corruption Court" (2018), etc.);

4) responsibility for offenses (Criminal Code of Ukraine, Code of Ukraine on Administrative Offenses, Civil Code of Ukraine, Disciplinary Statute of the Armed Forces of Ukraine).

Bylaws regulating corruption prevention in SBGSU include decrees of the President of Ukraine, resolutions of the Cabinet of Ministers of Ukraine, interdepartmental and SBGSU bylaws.

5. Participatorsof corruption prevention in SBGSU. They are createdforanti-corruption measures use. At the same time, the range of participatorsinvolved in this activity goes far beyond SBGSU units, because of it is part of the fight against corruption in Ukraine.

The corruption prevention participators in SBGSU should include:

International corruption prevention actors (UN, OSCE, CE, GRECO, NATO);

domestic anti-corruption actors:

governmental institutions (special anti-corruption authorized agencies (NABU, NAZK) and state bodies involved in the corruption prevention);

departmental bodies for corruption prevention (heads of departments; units of internal and self-security; authorized units (persons) for the prevention and detection of corruption in SBGSU);

non-government organizations, individuals and legal entities

6. Corruption prevent measures in SBGSU. General social measures include management system reforming, government openness ensuring, civic consciousness level raising. All of themshould be aimed at forming anti-corruption legal awareness and SBGSU staff resilience.

The corruption prevent general social measures influence is carried out on the border guard's personality formation until his entry into SBGSU service. But this influence continues during the service. Thus, the social reforms impact is transformed through the border guards' social support; educational activities - through educational work and psychological support etc.

In turn, special criminological measures are the subject of corruption prevention programs, plans, guidelines, etc. (Melnyk,2004: 268). These measures content and intensity in SBGSU are correlated with corruption risks in official activity given area. Thus, in order to prevent corruption, during border control border guards are prohibited from: 1) accepting any items (things) from any persons and passing items (things) to anyone; 2) provide anyone with information about persons, vehicles, goods moving across the state border or through checkpoints of entry - exit, unless otherwise provided by law; 3) provide advantages in crossing the state border or entering and leaving the temporarily occupied territory to persons, vehicles and goods; 4) have any personal communication means are not part of the border guard equipment; 5) carry cash in excess of the amount established by the SBGSU Administration.

In order to corruption effects minimize in SBGSU, considerable attention is paid to work with staff:

providing staff with methodological and consulting assistance on compliance with anticorruption legislation;

implementation of measures to identify conflicts of interest, promote its settlement; ensuring the whistleblowers protection (Stepanov, 2020). 
This personality approach (anti-corruption influence object is a concrete entity) demonstrates its effectiveness. Anyway, final decision has to be approved by each border guard himself. This is confirmed by the significant number of border guards 'refusals from illegal benefits (DPSU Antykoruptsiinyi biuleten, 2020).

At the same time, it should be recognized that there is an urgent need to improve approaches to SBGSU staff selection. Educational activities and training aimed to their anticorruption resilience formation also extremely important. Today, there are staffing projects "New Face of the Border" and "New Face of Management", implemented with the US Embassy in Ukraine and IOM support.

However, there is need of the militaries` responsibility strengthening, the inevitability of criminal liability ensuring, and monitoring compliance with moral and ethical norms. It is also promising to improve the system tools for self-motivation and motivation based on a set of material and moral and ethical incentives, improving the border agency image and SBGSU prestige.

\section{Conclusions}

In view of the above, it is possible to formulate a number of theses having a direct importance for current situation understanding and corruption prevention spheres in SBGSU:

SBGSU anti-corruption system is characterized by international, domestic and departmental institutions and instruments interaction. It is a part of domestic anti-corruption system and includes such elements: object, goals, principles, legal framework, participators and measures of prevention;

range of participators involved in SBGSU corruption prevention extends beyond the borderguard agency. It is proposed to consider anti-corruption participators powers based on such classification: 1) international actors; 2) domestic actors: governmental institutions (special anti-corruption authorized agencies and state bodies involved in the corruption prevention); departmental bodies for corruption prevention; non-government organizations, individuals and legal entities;

corruption prevention in SBGSU should be based on self-service activities for integrity and staff corruption resistance level increasing. Combating illegal activities at the state border (smuggling, drug trafficking, human trafficking) is also actual for anti-corruption objectives achieving.

\section{References}

Antykoruptsiina prohrama Derzhavnoi prykordonnoi sluzhby Ukrainy na 2020-2022 roky [SBGSU Anti-corruption program for 2020-2022]. Retrieved from https://dpsu.gov.ua/ua/corrupt/ [in Ukrainian].

Chene M. (2018). Corruption at borders. U4. Chr. Michelsen institute. Retrieved from https:// www.u4.no/publications/corruption-at-borders.pdf.

Derzhavna prykordonna sluzhba Ukrainy. Antykoruptsiinyi biuleten za 2020 rik [SBGSU. Anti-Corruption Bulletin for 2020]. Retrieved from https://dpsu.gov.ua/upload/\%D0\%97apobigannja_korypcii/\%D0\%90ntikorypcijnij_bjuleten.pdf [in Ukrainian].

Derzhavna prykordonna sluzhba Ukrainy. Antykoruptsiinyi biuleten za I pivrichchia 2021 roku [SBGSU. Anti-Corruption Bulletin for I half, 2021]. Retrieved from https://dpsu.gov.ua/ua/ antikorupciyni-byuleten/ [in Ukrainian]. 
Filippov S. O. (2019). Kryminolohichni zasady protydii transkordonnii zlochynnosti [Criminological principles of cross-border crime counteracting]. Doctoral Dissertation. Natsionalna akademiia Derzhavnoi prykordonnoi sluzhby Ukrainy imeni Bohdana Khmelnytskoho, Khmelnytskyi. Dnipropetrovskyi derzhavnyi universytet vnutrishnikh sprav, Dnipro [in Ukrainian].

Filippov S. O., Zolka V. L. (2013). Zapobihannia ta protydiia koruptsii: navchalno-metodychnyi posibnyk (dlia provedennia navchalnoho kursu v uchbovykh zakladakh prykordonnykh $i$ mytnykh vidomstv Respubliky Moldova ta Ukrainy) [Preventing and combating corruption: a training manual (for a training course in educational institutions of the border and customs departments of the Republic of Moldova and Ukraine]. Odesa [in Ukrainian].

Holovkin B. M. (2018). Mekhanizm zapobihannia koruptsii [Corruption prevention mechanism]. Chasopys Kyivskoho universytetu prava, 4. pp. 254-260 [in Ukrainian].

Hrabálek M. (2010). Ochranahranic EU a role agentury FRONTEX v ní [EU border protection and the role of FRONTEX in it]. Disertačnípráce. Masarykova univerzita, Brno [in Czech].

Kuryliuk Yu. B. (2019). Kharakterystyka osoby prykordonnyka, yakyi vchyniaie koruptsiinyi zlochyn [Border guard personality characteristics commiting a corruption crime].Pytannia borotby zi zlochynnistiu, 38. pp. 141-155. Retrieved from http://pbz.nlu.edu.ua/article/ view/181274 [in Ukrainian].

Kuryliuk Yu. B. (2020). Administratyvno-pravovi ta kryminolohichni zasady zabezpechennia pravoporiadku $v$ prykordonnii sferi Ukrainy [Administrative and legal and criminological aspekts ensuring law and order in the border sphere]. Doctoral Dissertation. Klasychnyi pryvatny iuniversytet, Zaporizhzhia [in Ukrainian].

Melnyk M. (2004). Koruptsiia - koroziia vlady (sotsialna sutnist, tendentsii ta naslidky, zakhody protydii) [Corruption as a corrosion of power (social essence, trends and consequences, preventive measures)]. Monohrafiia. Kyiv:Yurydychna dumka [in Ukrainian].

Regulation (EU) 2019/1896 of the European parliament and of the council of 13 November 2019 on the European Border and Coast Guard and repealing Regulations (EU) No 1052/2013 and (EU) 2016/1624. Retrieved from https://eur-lex.europa.eu/legal-content/ EN/TXT/?qid=1573722151667\&uri=CELEX:32019R1896.

Stepanov S. P. (2020). Shchodo zakhodiv zapobihannia koruptsii sered prykordonnykiv [On measures to corruption prevent among border guards]. Osvitno-naukove zabezpechennia diialnosti skladovykh sektoru bezpeky y oborony Ukrainy: tezy XII Vseukrainskoi naukovo-praktychnoi konferentsii (Khmelnytskyi, 26 lystopada 2020 roku). Khmelnytskyi. pp. 392-394 [in Ukrainian].

Wells N. (2019). Study: Stricter US Border Control Increases Corruption. Organized crime and corruption reporting project. Retrieved from https://www.occrp.org/en/daily/10839-study-stricter-us-border-control-increases-corruption.

Zapobihannia ta protydiia koruptsii: navch. posib. (2013) [Preventing and combating corruption] / Mykhnenko A. M., Rusnak O. V., Mudrov A. M., etc. Kyiv: Akademiia finansovoho upravlinnia [in Ukrainian].

Zvit pro vykonannia Antykoruptsiinoi prohramy Derzhavnoi prykordonnoi sluzhby Ukrainy na 2020-2022 roky [Report on the implementation of the SBGSU Anti-Corruption Program for 2020-2022]. Retrieved from https://dpsu.gov.ua/ua/antikorupciyna-programa-/[in Ukrainian]. 